\section{Sources of Curly Top Virus Resistance in Capsicum}

\author{
Paul W. Bosland \\ Agronomy and Horticulture Department, New Mexico State University, \\ Las Cruces, NM 88003-0003
}

Additional index words. chile, pepper, cultivar, beet curly top virus, Capsicum annuum, Capsicum baccatum, Capsicum chacoense, Capsicum chinense, Capsicum frutescens

\begin{abstract}
During a natural field epidemic of curly top virus, accessions within five species of Capsicum were evaluated for resistance. Accessions were considered resistant if $0 \%$ to $25 \%$ of the individual plants were devoid of curly top virus symptoms. Resistance was found in three accessions each of $C$. annuum $\mathrm{L}$. and $C$. frutescens $\mathrm{L}$. and one accession each of $C$. chacoense Hunz. and $C$. chinense Jacq. The resistant $C$. annuum accessions were 'Burpee Chiltepin', 'NuMex Bailey Piquin', and 'NuMex Twilight', while the $C$. frutescens resistant accessions were USDA-Grif 9322 from Costa Rica, PI 241675 from Ecuador and 'Tabasco'. The resistant $C$. chacoense accession was PI 273419 from Argentina and the $C$. chinense resistant accession was USDA-Grif 9303 from Colombia.
\end{abstract}

Curly top virus (syn. beet curly top virus), a geminivirus vectored by the leafhopper, Circulifer tenellus (Baker), is found primarily in arid and semi-arid climates. In southern New Mexico, it occurs annually in chile pepper (Capsicum annuum L.) fields (Muhyi and Bosland, 1989). Typical symptoms of curly top on young chile plants include yellowing of leaves, dwarfism, and death. If the plant survives, the few pods produced are deformed and small. The margins of older leaves roll upward and they become thickened and leathery (Bosland et al., 1988).

In most years, curly top damage to chile is minimal in New Mexico. During Spring 1999, the Mesilla and Hatch Valleys, including the

Received for publication 6 Aug. 1999. Accepted for publication 14 Feb. 2000. A contribution of the New Mexico Agricultural Experiment Station, New Mexico State Univ., Las Cruces. The cost of publishing this paper was defrayed in part by the payment of page charges. Under postal regulations, this paper therefore must be hereby marked advertisement solely to indicate this fact. research plots at New Mexico State Univ., experienced extremely high levels of curly top virus infection. The epidemic may have been weather-related, with a cool spring keeping the migratory leafhoppers in the area longer than usual. The virus survives in the bodies of the leafhoppers, which transmit the virus to chile plants during feeding. The Chile Pepper Institute's Teaching and Demonstration Garden, planted annually at the Fabian Garcia Science Center in Las Cruces, N.M., had 127 accessions of chile and 56 accessions of tomato (Lycopersicon esculentum Mill.) planted for the season. The curly top virus epidemic was so severe that all tomato accessions were killed. Some chile plants survived, providing an opportunity to observe possible resistance among the planted material under natural infection. An earlier survey of U.S. Dept. of Agriculture plant introductions reported resistance in some Capsicum accessions (Ungs et al., 1977). This note provides information on additional potential sources of resistance to curly top virus in Capsicum.
Each of the 127 chile accessions evaluated contained up to 12 individual plants and each plant was scored symptomatic or asymptomatic by visual assessment. A single symptomatic plant from four different accessions and one plant that had no symptoms of curly top were sent to a testing laboratory (AGDIA, Elkhart, Ind.) to confirm that curly top virus was present. The test confirmed that curly top was present, and no other viruses were detected. The plant without symptoms was free of the virus. Therefore, plants with one or more symptoms of the disease were considered infected. All symptomatic plants, whether expression was mild or severe, were classified as infected; all other plants were asymptomatic. The symptomless individuals may have been escapes, but this is unlikely because of the severity of the epidemic. However, the symptomless plants could be tolerant to the virus. Confirmation of whether the symptomless plants were truly resistant or tolerant was beyond the scope of these observations.

The accessions were grouped by percentage of plants showing symptoms (Tables 1 and 2 ). The data indicate that those accessions are worthy of further testing, and may be useful sources of resistance to the virus. Those accessions with $75 \%$ or more symptomatic plants may not be the best starting point for sources of resistance. Individuals within these accessions may be resistant, but the frequency is low, making identification arduous. However, the eight accessions in the $0 \%$ to $24 \%$ symptomatic group and the 10 accessions in the $25 \%$ to $50 \%$ warrant further evaluation, and could be useful sources of resistance in chile breeding programs.

\section{Results}

All eight accessions in the group with the lowest percentage of symptoms are wild types. Capsicum chacoense Hunz. is a wild species, and the three $C$. annuum accessions are chiltepin types. The $C$. chinense Jacq. and $C$. frutescens L. accessions are also small-fruited, wild types. The genetic diversity present in wild species plays an important role in crop improvement.

Table 1. Reactions of Capsicum annuum genotypes to a natural epidemic of curly top virus.

\begin{tabular}{|c|c|}
\hline Burpee Chiltepin, NuMex Bailey Piquin, I & $\begin{array}{l}\% \text { to } 25 \% \text { symptomatic }{ }^{z} \text { plants within an accession } \\
\text { uMex Twilight }\end{array}$ \\
\hline Black Olive, Milky Way, Mississippi Sp & $\begin{array}{l}\text { Yo to } 50 \% \text { symptomatic plants within an accession } \\
\text { NuMex Piñata, Ordono, PI } 439378 \text { (Jamaica), Sujata, Tarahumara Chiltepin, Thai Hot }\end{array}$ \\
\hline $\begin{array}{l}\text { Big Red, de Arbol, Golden Giant II, Hot Pc } \\
\text { Sunflare, NuMex Pinata, NuMex Sunglo, }\end{array}$ & $\begin{array}{l}\text { \% to } 75 \% \text { symptomatic plants within an accession } \\
\text { ugal, Huasteco, Jigsaw, Long Red Cayenne, Mississippi Sport, NuMex Joe E. Parker, NuMex } \\
\text { ter Pepper, Pinguita de Mono, Serrano, Valencia }\end{array}$ \\
\hline $\begin{array}{l}\text { Ancho, Antohi Romanian, Apple, Big Ber } \\
\text { Cubanelle, Flamingo, Golden Summer, Gu } \\
\text { Lavender Apple Islander, Lemon Belle, I } \\
\text { Mexico 6-4, NuMex Big Jim, NuMex Conq } \\
\text { NuMex Primavera, Ole, Orange Belle, Pasi } \\
\text { Queen Bell, Sandia, San Felipe, San Juan, } \\
\text { Dragon, Yellow Cayenne, Yellow Flame }\end{array}$ & $\begin{array}{l}\text { 6\% to } 100 \% \text { symptomatic plants within an accession } \\
\text { na, Big Chile, Big Thai, Biscayne, Chilaca, Chile de Arbol, Chimayo, Cochiti, Corno de Toro, } \\
\text { ajillo, Isleta, Jackpot, Jemez, Jingle Bells, Kishiner, Kori Sitakne, LaMuyo, Large Red Cherry, } \\
\text { ong Slim Cayenne, Mandarin, Marconi, Mesilla Cayenne, Mirasol, Mushroom, Negro, New } \\
\text { istador, NuMex Rio Grande, NuMex Sunburst, NuMex Eclipse, NuMex Sunset, NuMex Sunrise, } \\
\text { a, Perfecto, Pepperoncini, PI 599426, Piment de Cayenne, Pimento Select, Pulla, Purple Beauty, } \\
\text { csile, Santaka, Santo Domingo, Sugar-chile, Super Cayenne II, Sweet Banana, Tejaswini, Thai }\end{array}$ \\
\hline
\end{tabular}

${ }^{\mathrm{z}}$ Symptomatic plants had visible symptoms of curly top disease. 
Table 2. Reactions of genotypes of four species of Capsicum to a natural epidemic of curly top virus.

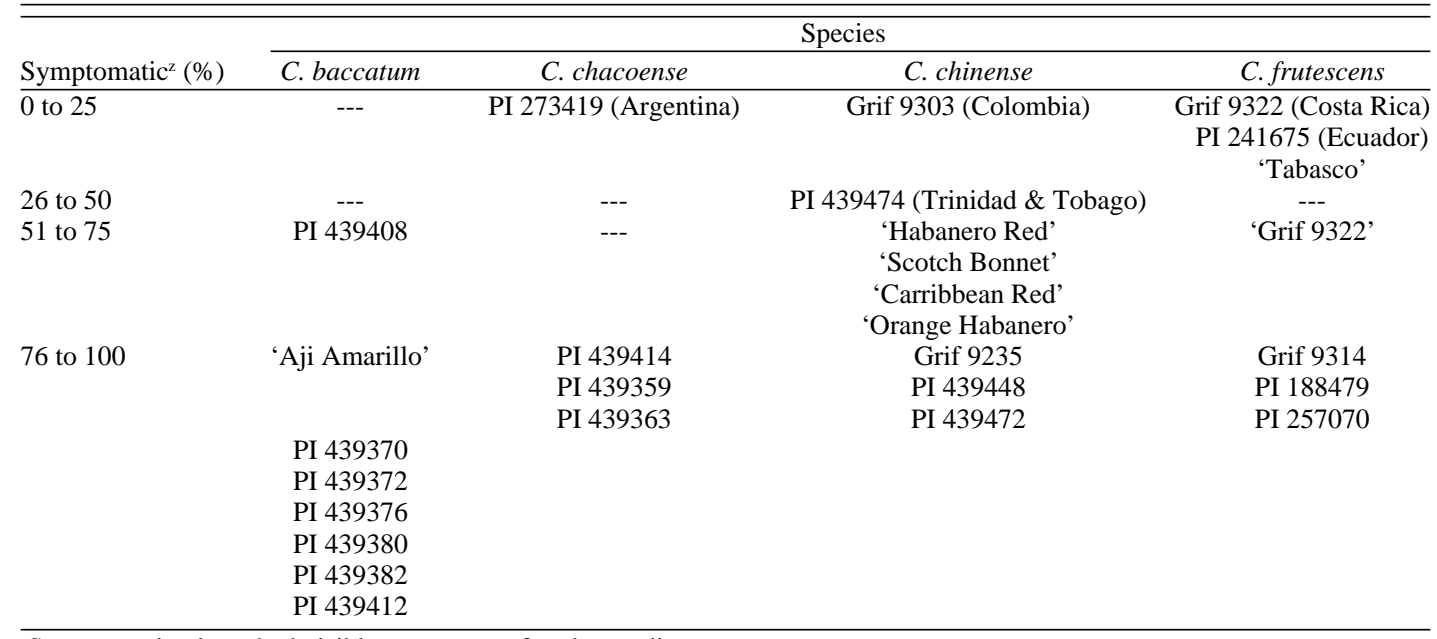

${ }^{2}$ Symptomatic plants had visible symptoms of curly top disease.

Wild and weedy forms of domesticated chile are known sources of novel and useful genes (Gonzalez and Bosland, 1991). The wild relatives of domesticated chiles have not been evaluated extensively; however, this survey illustrates their potential utility for breeding curly top resistance.

\section{Literature Cited}

Bosland, P.W., D. Lindsey, M. Loftin, and M. Wright. 1988. Diagnosing plant disorders in the southwest. $1^{\text {st }}$ ed. New Mexico State Univ., Las Cruces, N.M.

Gonzalez, M.M. and P.W. Bosland. 1991. Strategies for stemming genetic erosion of Capsicum germplasm in the Americas. Diversity 7:52-53. Muhyi, R.I. and P.W. Bosland. 1989. A survey identifying pepper viruses occurring in southern New Mexico. HortScience 24:93.

Ungs, W.D., C.G. Woodbridge, and A.A. Csizinszky. 1977. Screening peppers for resistance to curly top virus. HortScience 12:161162. 